\title{
The Promised Land
}

Lawson, Peter; Gilbert, Ruth; Abrams, Nathan

\section{Journal of European Popular Culture}

Published: 01/04/2016

Peer reviewed version

Cyswllt i'r cyhoeddiad / Link to publication

Dyfyniad o'r fersiwn a gyhoeddwyd / Citation for published version (APA):

Lawson, P., Gilbert, R., \& Abrams, N. (2016). The Promised Land: Utopia and Dystopia in Contemporary British Jewish Literature. Journal of European Popular Culture, 7(1), 3-8.

\footnotetext{
Hawliau Cyffredinol / General rights

Copyright and moral rights for the publications made accessible in the public portal are retained by the authors and/or other copyright owners and it is a condition of accessing publications that users recognise and abide by the legal requirements associated with these rights.

- Users may download and print one copy of any publication from the public portal for the purpose of private study or research.

- You may not further distribute the material or use it for any profit-making activity or commercial gain

- You may freely distribute the URL identifying the publication in the public portal ?
}

Take down policy

If you believe that this document breaches copyright please contact us providing details, and we will remove access to the work immediately and investigate your claim. 
The Promised Land: Utopia and Dystopia in Contemporary British Jewish Literature

\section{Introduction}

This special issue of the Journal of European Popular Culture stems from a British Jewish: Contemporary Culture (BJ:CC) conference, which was held at the Open University London and South East Regional Centre in July 2015. The papers presented at the conference contributed in a fascinating variety of ways to the theme of utopia/dystopia in contemporary British Jewish culture. There were three panels, covering the areas of 'Jewish Utopia/Dystopia', 'Film and Television Utopia/Dystopia' and 'Literary Utopia/Dystopia'. This special volume of the Journal of European Popular Culture draws from the literary strand of the proceedings, but is implicitly informed by the range of contributions across disciplines as well as the discussions about utopia/dystopia that flowed throughout the day.

From the outset, we set out to question any simple definitions of either utopia or dystopia and, as the day progressed, it became clear that we were looking at far more than a simple dichotomy between two mutually opposed terms. Instead, these were clearly interdependent and complex concepts. As Professor Sue Vice argued in her insightful reading of the BBC TV series The Honourable Woman (2014), 'the clash between the tropes of utopia and dystopia' revealed how such a binary opposition could not be sustained. Instead, she proposed the evocative term 'neutropia' to describe the breakdown of such dualist thinking (Vice 2015). 
So, a day that started with a discussion of messianism and British Jewish utopia, and went on to consider issues of (amongst other matters) 'New Jerusalems', forgotten texts, home, diaspora, 'race', promised lands and dystopian nightmares, concluded with a discussion of heterotopian 'other' spaces, asking if this somewhat oblique strategy might perhaps speak to, and for, contemporary British Jewish culture.

An engaging and insightful keynote lecture from Professor Bryan Cheyette on 'British Jewish Utopias and Dystopias from Zangwill to Jacobson' made a strong case for understanding the contemporary within British Jewish culture in terms of its historical traces. This special issue of the Journal of European Popular Culture, whilst focusing explicitly on an exploration of contemporary British Jewish culture, is informed in a number of ways by Cheyette's methodological imperative.

Following the academic presentations and discussions, delegates were invited to the launch of poet Jasmine Donahaye's memoir Losing Israel (2015), a lyrical reflection on Wales, Palestine and Israel. This shift, into a different kind of discursive space, constellated many of the themes that had been in circulation throughout the day.

\section{From More to messianism: historical and philosophical contexts}

'Utopia' is firmly linked with Thomas More's book of that name, published 500 years ago in 1516. More was an Englishman. Again, the term 'dystopia' was coined by another Englishman, John Stuart Mill. He 
used the word dystopia as synonymous with cacotopia, a neologism that had been invented by Jeremy Bentham; and the two words have in fact a similar etymology and intention: $d y s$ comes from the Greek dus, and means bad, abnormal, diseased; caco comes from the Greek kako, which is used to refer to something which is unpleasant or incorrect. (Vieira 2010: 16) [the change from text to display is confirmed]

Thus More, Mill and Bentham provide us with the universal - and particularly English framework for this special issue of the Journal of European Popular Culture

Whereas More's Utopia sets itself within a Greek-Christian-Renaissance tradition of utopian thought and literature, there is another root of utopian thinking in Europe: Judaic messianism. It stems from the Jewish religion, but branches into secular manifestations. As Manuel and Manuel explain, 'trust in a messianic age at an unknown future time is one of the constants of postexilic Judaic religion' (1979: 29). This messianism flowered in real historical conditions. As Jacqueline Dutton neatly summarizes:

$[U] n d e r$ the reign of the more tolerant Persian King Koresh, the 'children of exile' started to return to Jerusalem around $540 \mathrm{BCE}$ and began the construction of the Second Temple, completed in 515 BCE, which heralded a flourishing new era for Jerusalem and Judaism. When the Second Temple was destroyed by the Romans around $70 \mathrm{CE}$, the systemic persecution and enslavement of the Jews marked the end of what may be considered the Golden Age of Jewish practice and cultural development in Jerusalem, and provoked eschatological visions of a Third Temple, coinciding with the coming of the Messiah. The messianic predictions of the 
reconstruction of the centre of Judaism in Jerusalem are therefore closely related to the particular historical traditions of an ideal existence in Jewish thought. (Dutton 2010: 232-33)

So, ancient Jewish persecution led to utopian visions that were closely related to both a real place ('Jerusalem') and universalist dreams ('the coming of the Messiah').

Although this issue of JEPC considers contemporary British Jewish literary manifestations of utopia and dystopia, this specifically British (and English) context is worth bearing in mind. Equally, we should not lose sight of the wider European intellectual context. In our discussion of Jewish messianic thought, British cultural insularity is decidedly unhelpful. Although our guest-edited issue of JEPC focuses on novels and poems by British Jewish writers, the ideas of Martin Buber, Walter Benjamin and Ernst Bloch; Erich Fromm, Georg Lukács and Theodor Adorno; Jacques Derrida, Emanuel Levinas and Hannah Arendt, as well as other significant European Jewish thinkers, should not be discounted (Namli et al. 2014). [Now in bibliography] Jewish messianism, we want to suggest, finds its secular voice in the European works of such intellectuals; and this impacts on British Jewish literature.

It is also worth identifying, from the outset, the difference between Jewish messianism and More's brand of utopia. More's Utopia does not depict a perfect place. In this, it resembles Plato's Republic (380 BCE) in simply describing the best organization of a city; although it goes further in depicting an actually existing place. Again, it resembles Augustine's City of God (426 CE). However, Augustine's vision is explicitly Christian and constructs a city for the afterlife ('an alotopia') (Vieira 2010: 6). More draws on Greek and Christian traditions to 
create something unique: a Hellenised Renaissance City-State which is the best he can imagine in the fallen Christian world he sees around him. Indeed, More's Utopia could not be about perfection. This would be impossible within his Christian world-view, with a belief in the Fall of Man. What his book offers instead is 'an ability to arrange society differently in order to ensure peace' (Vieira 2010: 4). Part I of Utopia consists in a critique of Europe - and particularly England. What follows in Part II is a description of a much better place, which in some ways resembles the British Isles. More's Utopia is a well-fortified, colonialist island. It is what England might become were it less susceptible to venality and irrational cronyism, and more concerned with encouraging all its citizens (More 1982). Indeed, Utopia can be read as a political manifesto. What it proposes can be done. [now included in bibliography]

By contrast, Jewish messianism tends to envisage a revolutionary transformation of society in utopian projects such as communism, Zionism and liberalism. The same applies to dystopia in relation to British Jewish literature, whether the subject addressed be antisemitism, Nazism, the Holocaust or contemporary Britain as a failed multicultural space. What we find depicted, for example, in Howard Jacobson's J (2014) (discussed in Ruth Gilbert's “"No Outlines": From dystopia to heterotopia in Howard Jacobson's J') is not merely worse than contemporary Britain. Rather, the scenario resembles a post-apocalyptic transformation of Britain. Gershom Scholem [this spelling is correct] writes of

the catastrophic nature of redemption as a decisive characteristic of every such apocalypticism, which is then complemented by the utopian view of the content of realized redemption. Apocalyptic thinking always contains the elements of dread and consolation intertwined. The dread and peril of the End form an element of shock and 
of the shocking which induces extravagance. The terrors of the real historical experiences of the Jewish people are joined with images drawn from the heritage of myth or mythical fantasy. This is expressed with particular forcefulness in the concept of the birth pangs of the Messiah which in this case means the Messianic age. (1974: 10)

'Catastrophic' apocalypticism here resembles redemptive messianism, the two being complementary, 'intertwined' and 'joined'. Both are 'shocking', and so we should not be overly surprised to find such 'shock' and 'extravagance' in utopian and dystopian British Jewish literature.

This issue of the Journal of European Popular Culture focuses on how contemporary British Jewish literature responds to such utopian and dystopian narratives. These narratives, we want to suggest, oscillate between a messianism and a dystopianism often based on constructions of antisemitism in Britain and beyond.

\section{From the Promised Land to Losing Israel: Essays}

In placing Jewishness within this utopian/dystopian framework, the essays collected here draw from poetry, novels and memoir to consider themes of loss and belonging, possession and dispossession, home and diaspora.

Dreams of the Promised Land are deeply embedded within the Jewish imagination, and expressions of yearning for the land of milk and honey structure many reflections on 
Jewishness, both historically and in more recent times. This utopian imperative appears, for example, in Theodor Herzl's Altneuland (1902), a utopian novel that sets out some of the founding principles of Zionism. However, this is a complex and somewhat ambiguous ideal. In some senses, the utopian imperative within Judaism, an eternal waiting within a condition of projected idealism, means that Jews are caught potentially in a condition of endless deferral. Moreover, as the recent history and present circumstances of Israel/Palestine suggests, the actualities of place, people and politics, in reality, rather than in a utopian vision, are far from ideal. Arguably, the utopianism that underpinned some of the founding visions of Zionism might equally be figured, from the Palestinian perspective, as a dystopian nightmare.

These themes inflect a number of the essays collected here. In 'Utopia, Palestine, and partition: Herbert Samuel's An Unknown Land (1942)', Finn Fordham traces the imperialist underpinning of Zionist developments in his reading of Herbert Samuel's utopian fiction. From a more contemporary and personal perspective, Jasmine Donahaye draws from her own family history (specifically the discovery of her family's collusion in the displacement of Palestinians) in a creative travelogue which sets out to reconcile her conflicted feelings in relation to national longing and belonging.

The utopian vision and dystopian disillusionment that Donahaye's piece evokes are themes that also run through the exploration of poetic texts in essays by Merle Bachman and Peter Lawson. Bachman's reading of the diasporic poetry of the Scottish Jewish poet A.C. Jacobs, in terms of its navigation of a 'possible third space, neither utopian nor dystopian' (Bachman), offers a subtle insight into Jewish 'space and place' that also hints at the 
romance of imagined exile. Lawson's essay, which focuses on ways in which British Jewish poets Ruth Fainlight and Elaine Feinstein respond to utopian and dystopian paradigms, argues that 'whilst Ruth Fainlight seeks an aestheticised utopia in art, Elaine Feinstein constructs a romanticized exilic utopia' (Lawson).

An interest in issues of spatiality, and how this relates to the figuration of Jewish utopia and dystopia, is evident in other essays. Ruth Gilbert, for example, reads Howard Jacobson's dystopian novel $J$ in the light of Foucault's conceptualization of heterotopia to argue that such a reading 'perhaps offers a more expansive and nuanced approach to exploring the ways in which Jewishness is both distilled and filtered within and beyond this text' (Gilbert). Underlying Jacobson's imagined future, in which Jewishness has seemingly been annihilated, discourses of antisemitism and the Holocaust are never far away.

The Holocaust subtends several of these essays. For example, Eric Sandberg's reflections on Michael Moorcock's Pyat Quartet (1981-2006) 'explores the failure of the twentieth century's utopian impulses through its central character, Colonel Pyat... a self-denying Jew who...is exposed directly to the century's two great utopian movements, communism and fascism' (Sandberg).

As the terms 'Jew', 'Briton' and 'European' continue to evolve, our hope is that these essays will stimulate further discussion of utopian and dystopian cultural spaces. 
Our special thanks are extended to Alex Tickell and the Open University's Postcolonial Literatures Research Group which hosted 'The Promised Land: Utopia and Dystopia in Contemporary British Jewish Culture' conference, on which this collection of essays is based.

Peter Lawson (Open University), Ruth Gilbert (University of Winchester), Nathan Abrams (Bangor University)

\section{References}

Donahaye, Jasmine (2015), Losing Israel, Bridgend: Seren Books.

Dutton, Jacqueline (2010), “"Non-western” utopian traditions', in Gregory Claeys (ed.), The Cambridge Companion to Utopian Literature, Cambridge: Cambridge University Press, pp. 223-58.

Manuel, Frank E. and Manuel, Fritzie P. (1979), Utopian Thought in the Western World, Cambridge, MA: The Belknap Press of Harvard University Press.

More, Thomas, (1982), Utopia, Harmondsworth, Middlesex: Penguin.

Namli, Elena, Svenungsson, Jayne and Vincent, Alana M. (eds.) (2014), Jewish Thought, Utopia and Revolution, Amsterdam-New York: Rodopi. 
Scholem, Gershom (1974), The Messianic Idea in Judaism, New York: Schocken Books.

The Honourable Woman (2014, UK: BBC)

Vieira, Fátima (2010), 'The Concept of Utopia', in Gregory Claeys (ed.), The Cambridge Companion to Utopian Literature, Cambridge: Cambridge University Press, pp. 3-27.

Vice, Sue (2015), 'Tragedy or Neutropia? The Honourable Woman', In Open University Postcolonial Literatures Research Group, The Promised Land: Utopia and Dystopia in Contemporary British Jewish Culture, 23 July 2015, Open University: London. 